\title{
CHARACTERISTICS PHYSICAL PROPERTIES OF SOIL FOR CONSERVATION POND PLANNING IN KECAMATAN LIANG ANGGANG PEATLANDS
}

\author{
Rusliansyah, Rusdiansyah, Muhammad Afief Ma'ruf, Meilinda Ayunita Santoso \\ Civil Engineering Department, Engineering Faculty \\ Lambung Mangkurat University, South Kalimantan, Indonesia
}

Email: afief.maruf@ulm.ac.id

\begin{abstract}
Peatland fires in 2015 that hit 23 of 33 provinces in Indonesia is one of the worst fires in history. South Kalimantan is one of the 23 provinces with the burned land area of 19.179,9 hectares. Peatland burning in Banjarbaru and of Banjar Regency which totaled 1.536 fire point burning with a land area of approximately 1.500 hectares. The main factor of this land fires is of decreased water level in the peat land. Therefore, to overcome that fires will not happen again by creating a conservation pond to hold water, especially during the rainy season in order to keep moist peat. The planning an peat land conservation in this area of 900 hectares. Peat ecosystem restoration can be done through the realignment of hydrological function where peat dome as a long-term water storage. The purpose of the research is to knowing the state of the physical properties soil for conservation pond made and knowing the condition of the ground water level in the field. From the results of an investigation soil physical properties obtained peat has not undergone recast and the number of pores in the soil are very large so that the soil becomes porous with a high water level conditions.
\end{abstract}

Key words: peat soils, physical properties.

\section{INTRODUCTION}

Land and forest fires in Indonesia in 2015 ago was one of the worst in history. More than 2.6 million hectares of forests, peatlands and other land burned in 2015 (BBC, 2016). For region Kalimantan Selatan based on data in 2015, the number of spots to 9 November as many as 3,264 fires with an area burned is 211 995 hectares or 5.7 percent of the area of Kalimantan Selatan. As for the peat fires in Banjarbaru and Kabupaten Banjar until the month of September 2015 as many as 1,536 hotspots. (Antara Kal-Sel, 2016).

During the dry season in 2015 in the area Banjarbaru and Kabupaten Banjar fires in peatlands with an area of approximately 1500 hectares, where the dry season the peatland conditions occur overdrain excess that causes peat to dry and contains high carbon and lead to fires. The main factor of this land fires is decreased water level in the peat.

Solutions to overcome the smog caused by forest fires to create a channel blocking to hold water such as making storage ponds to hold water, especially during the rainy season in order to keep moist peat. Peat ecosystem restoration can be done through the realignment of the hydrological function where peat dome as a long storage of water, so the turf remained wet and difficult to burn. (Ministry of Environment and Forestry, 2015)

The research aimed to analyzing the state of the physical properties of the soil to made pond conservation of peatlands and knowing the condition of the ground water level in the field.

Swamp is a water container along with water and mains water contained in it, flooded constantly or seasonally, occur naturally in the land is relatively flat or concave with mineral deposits or peat, and overgrown vegetation, which is an ecosystem. (Indonesian Government Regulation No. 73 Year 2013, 2013). Wetland divided into three namely tidal wetlands, irrigation non tidal and inland wetlands.

Wetland has wide - range of functions that can be grouped into hydrological function, environmental protection, protected areas, cultivated areas, swamps strategic, environmental, social and economic.

For results In accordance with UU No. 7 of 2004 on water resources, wetlands are one of the potential of natural resources for the welfare of the community, so that potential in wetlands should be preserved and developed or enhanced functionality benefits. The potential use of wetlands is designated for development (extension) productive agricultural land, also function as natural resources (land and water) as well as conservation land. (Kodoatie, et al, 2010; Fauzi, 2016).

Problems of Swamp Development in Indonesia. There are some aspects that hinder 
the development of wetlands among other development activities marsh itself has obstacles in its implementation aspects of water (water management, flooding, drought, $\mathrm{pH}$, salinity, etc.), aspect soil (pyrite, peat, easy to grow weeds, nutrient-poor, etc.), socio-cultural aspects of the economy (residential, marketing, tillers, transportation, capital constraints, isolation, etc.), and environmental aspects. Here's an explanation of the various aspects. (Kodoatie J. \& Sjarief, 2010)

The conceptmarsh area of integrated management is a pattern of swamp development policy forward. The integration in the management and development of swamp areas include:

a. The integration in the management of the sectorswamp.

b. Integration of management and development plans as a source of water swamp in river basin management planning.

c. The integration of sector program support related sectors as a basis for the development of the area of reclaimed land in a sustainable manner. (Kodoatie J. \& Sjarief, 2010)

Peat soil has the ability to store water up to 13 times of its weight. It is therefore extremely important role in hydrology, such as controlling floods during the rainy season when the water reserve and issued a drought. The damage occurred on peat soil could lead to disaster for the surrounding area. (Fitriati and Ma'ruf, 2017).

Peat as the organic material is a source of energy, materials for seed germination media and organic fertilizer while peat as organic soil is used as land to agricultural activities and can be managed in the farm system. There are three kinds of soil organic matter decomposition is known by the level of the original plant material that is fibric, hemik and sapric. (Nugroho, et al, 2004)

Peatlands less economic value but have ecological functions but has a very important ecological functions, such as hydrological functions that play a role in regulating the flow and save water. A high ability to absorb water makes peat bogs play a role in preventing flooding and reduce the danger of flooding. (Nugroho, et al, 2004).

The physical characteristics of peatis important in utilization for agriculture include high moisture content, bulk density is low, power load bearing (bearing capacity) very low, subsidence, and drying is not good (irriversible drying) (Fitriati, Rusliansyah and Ma'ruf, 2017).
Chemical characteristics of the peatlands in Indonesia is largely determined by the mineral content, thickness, type of minerals in the substratum (at the base of peat), and the degree of decomposition of peat. The mineral content of peat in Indonesia is generally less than $5 \%$ and the rest is organic material. (Agus \& Subiksa 2008).

In the dry season, peatlands are very dry to a certain depth and flammable. Peat contains fuel (the rest of the plant) to below the surface, so the peatland fires spread below the soil surface and the slow and difficult to detect and causing thick smoke. Peatland fires difficult to extinguish so it could take a while (months). And, just to die miserably after the rain intensified. (WWF Indonesia, 2015).

Restoration of peatland ecosystems can be done through the realignment of the hydrological function where peat dome as a long-term water storage (longstorage of water), so the turf remained wet and difficult to burn (Robroek, et al, 2017).

Physical properties of peat soil parameter that plays an important role is the water content, the specific gravity, water content, void ratio, acidity, seepage, and bulk density. Is known to three (3) phases of soil solid phase (solid), liquid phase (liquid), and the gas phase, as well as for peat. Differences between peat and other land lies in the solid phase (solid) on peat soil where the solid phase is not always a solid part because peat fiber typically contains water and gas. Pori on fibrous peat soil according to MacFarlane, Muskeg Engineering Handbook (1965) is divided into macro-pores (pores between fiber - fiber is great) and micro pores (pores inside the fiber). (Source: Mochtar \& all, 1999).

It is generally known that the decreased water level causing further decomposition process on a layer above the groundwater table (Fitriati and Suryanur, 2017). The results showed that the determination of the level of maturity of peat with the three methods used have not been able to explain the differences in the level of decomposition that occurs in a layer of peat above and below the ground water level, because as if there are differences in maturity levels between the layers above and below the surface groundwater. Further decomposition process in a layer of peat above the ground water level also causes changes in various characteristics of the peat. (Nogroho \& Mulyanto, 2003) 


\section{MATERIALS AND METHODS}

Primary data is data obtained directly by researchers. Primary data were collected by field observation, the data obtained from the field is handboring for taking soil samples at the site for further study in a test laboratory.

Collect the data necessary to analyze the feasibility study of the conservation pool, such as:

a. Network maps or topographical maps showing the state of the areas of interest;

b. Handboring the data used to determine the ground state is visually and taken soil samples to be tested in a laboratory to determine the characteristics of the soil; Soil sampling by handboring for laboratory testing taken in 2017.

\section{RESULTS AND DISCUSSION}

\section{Analysis of Physical Properties of Peat Soil}

Water content of research results for the ratio between the weight of water contained in the soil mass to the weight of soil particle expressed in percent at $751.86 \%$ and $734.99 \%$. Peat soil is able to absorb water up to 13 times its weight. And according to Boelter (1969) peat soil moisture content that has not undergone a reshuffle range of $500 \%-1000 \%$ weighting, while a remodeled around $200 \%$ $600 \%$ weighting. This is what causes the peat sapat known as water-storage media very much.

The investigation contained peat soil volume weight of $0.99 \mathrm{~g} / \mathrm{cm} 3$ to $751.86 \%$ and a water content of $0.97 \mathrm{~g} / \mathrm{cm} 3$ to $734.99 \%$ moisture content. The density of the peat soil away very low compared to mineral soils in general. Bulk density peat soils vary between $0.01 \mathrm{~g} / \mathrm{cm} 3-0.20 \mathrm{~g} / \mathrm{cm} 3$, depending on the maturity of the constituent organic material. Heavy mineral soil volume ranges from $1.2 \mathrm{~g} /$ $\mathrm{cm} 3-1.8 \mathrm{~g} / \mathrm{cm} 3$ depending on the soil texture (Noor, 2001). From the results of the investigation's bulk density of peat soil peat soil weight is greater than the value in general but according Noor (2001) also on peatland has long cultivated the volume weight can be larger. Therefore, the volume weight value is influenced by several factors depending on the maturity of organic matter in the soil constituent and peat has long cultivated the weight of the volume can be larger.

Density of land is the ratio between the weight of soil grains by weight of distilled water in the air with the same volume at a given temperature. For this study gs value in getting an average of 0.78 . According to Bowles, organic soil have the specific gravity or gs value less than or equal to 2 . With the results obtained from the research results that correspond Bowles statement where peat in Indonesia is below a value of 2 .

The pore number $(\mathrm{e})$ is the ratio between the pore volume and the volume of the soil grains. (Hardiyatmo, 2002)

$$
e=\left(\frac{(1+w) \cdot G s \cdot \gamma w}{\gamma b}\right)-1
$$

For pore number with moisture content $751,86 \%$ with $\gamma w$ is $1 \mathrm{~g} / \mathrm{cm} 3$ obtainable:

$$
e=\left(\frac{(1+7,5186) \times 0,78 \times 1}{0,99}\right)-1=5,711
$$

And for pore rate with moisture content of $734,99 \%$ with $\gamma w$ is $1 \mathrm{~g} / \mathrm{cm} 3$ obtainable:

$$
e=\left(\frac{(1+7,3499) \times 0,78 \times 1}{0,97}\right)-1=5,714
$$

From the above calculation results obtained pore peat soil is 5.711 and 5.714 with an average of 5.7125. This result is in accordance with Mochtar's statement (1985, $1991,1998,1999,2000)$ Indonesia's peatland peat number has a pore value of 5-11.

Porosity $(n)$ is the ratio of pore volume to total soil volume. (Hardiyatmo, 2002)

$$
n=\frac{e}{1+e}
$$

For porosity value with $\mathrm{e}=5,71185 \%$ porosity value and for porosity with $\mathrm{e}=5,714$ porosity value $85,1 \%$ with $85 \%$ average. The amount of pore (e) in peat generally ranges from 5 to 15 (Hellis \& Brawner, 1961).

Can be seen in this study is very high porosity values it shows the number of pores in the soil so great that it makes the soil becomes more porous. Land which has a large degree of porosity which means having the pore space is large enough for water and air. The easier the soil to absorb water so that the soil has a great porosity as well as the peat soil.

The groundwater conditions in the peat area on two locations: around Sambang Lihum psychiatric hospital and JI. Sukamara Landasan Ulin. For Peat area Sambang Lihum in the groundwater in the area is submerged. The presence of water in peatlands is strongly influenced by the presence of rain and tide / low tide the river water. The behavior of both high and will affect the long puddles on peatlands. 
As for the runway area ironwood water level was $41 \mathrm{~cm}$ from the ground. Although it is not submerged but the water level is high.

In the dry season, the peatlands will be very dry to a certain depth until combustible. Peat contains fuel (plant remains) below the surface, so peat fire in the peatland is slowing down below the soil surface and is difficult to detect, causing thick smoke. The condition of peatlands overdrained so that land fires can not be avoided. Therefore, the water level on the peat land needs to be maintained with the creation of this conservation pond so that land fires do not reoccur.

\section{CONCLUSION}

The results of the investigation of soil physical properties are for these peat soil water level is still high which means that the peat has not undergone renovation, heavy value on peat soil volume smaller depending on the maturity of organic matter constituent, Gs value is small and the number of pores in the soil are very large so that the soil becomes porous.

Condition of ground water level in the peat field in Platform Ulin water level of $41 \mathrm{~cm}$, while in sambang lihum peat land submerged by water.

\section{REFERENCES}

Agus, F., \& Subiksa, I.M. (2008). Lahan Gambut: Potensi untuk Pertanian dan Aspek Lingkungan. Indonesia: Balai Penelitian Tanah dan World Agroforestry Centre (ICRAF). Bogor.

Antara Kalimantan Selatan (2016). Perlu Ahli Tangani Kebakaran Gambut. Banjarmasin.

BBC, I. (2016). Dapatkah kebakaran di Indonesia diakhiri? Jakarta: Sarah Porter.

Boelter, D. (1969). Physical Properties of Peat as Related to Degree of Decomposition. Proc. of the Soil Sci. Soc. of Am., 33: 606-609.

Fauzi, M. (2016). Agribusiness innovation in freshwater swamp through development of organic rice. Tropical Wetland Journal 2 (2): 15-19.

Fitriati, U., \& Ma'ruf, M.A., (2017). Proof that Canal Blocking at Peatlands in Sungai Ahas Central Kalimantan not Improve Water Quality. International Journal of ChemTech Research 10 (3): 24-31.

Fitriati, U., Rusliansyah, \& Ma'ruf, M.A., (2017). Canal Blocking to Maintain
Groundwater Level at Peatland Central Kalimantan. Journal of Applied Environmental and Biological Sciences 7 (4): 111-117.

Fitriati, U., \& Suryanur, F., (2017). Identification of Shallow Ground Water Use In District Martapura, South Borneo, Indonesia. Journal of Biodiversity and Environmental Sciences (JBES) 11 (4): 178-186.

Hellis, C., \& Brawner, C. (1961). The Compressibility of Peat with Reference to Major Highway Construction in British Columbia. Colombia: Proc. Seventh Muskeg Res. Conf, NRC. ACSSM. Tech, Memo 71: 204-227.

Ministry of Environment and Forestry. (2015). Pedoman Pemulihan Ekosistem Gambut. Jakarta.

MacFarlane, I. (1965). Muskeg Engineering Handbook. National Research Council of Canada, University of Toronto. Toronto. Canada.

Mochtar, N. E. (1985, 1991, 1998, 1999, 2000). Compression of Peat Soils. USA: Ph.D. Thesis Univ of Wisconsin Madison. USA.

Nogroho, T., \& Mulyanto, B. (2003). Pengaruh Penurunan Muka Air Tanah Terhadap Karakterisktik Gambut. Jurusan Tanah, Fakultas Pertanian IPB. Bogor:

Noor, M. (2001). Pertanian Lahan Gambut . Kanisius. Yogyakarta.

Nugroho, W.C. (2004). Panduan Pengendalian Kebakaran Hutan dan Lahan Gambut. Wetlands International - Indonesia Programme. Bogor:

Peraturan Pemerintah Republik Indonesia Nomor 73 Tahun 2013 (2013). Rawa. Lembaran Negara Republik Indonesia.

Robroek, B. J.M., et al., (2017). Taxonomic and functional turnover are decoupled in European peat bogs. Nature Communications 8: 1161. Retrieved from

www.nature.com/naturecommunicatio ns

Soemarto B.I.E Dipl H, I. (1987). Hidrologi Teknik. Usaha Nasional.Surabaya.

Supriyati, W., Alpian., Prayitno, A., Sumardi., \& Marsoe, S. N., (2016). Local wisdom in utilizing peat swamp soil and water to improve quality of gelam wood. Tropical Wetland Journal 2 (2): 27-37. 
Rusliansyah, Rusdiansyah, Muhammad Afief Ma'ruf, Meilinda Ayunita Santoso: Characteristics

WWF INDONESIA. (2015). Forest Fire. Diambil kembali dari Mungkinkah Penurunan Titik Panas Tercapai?: Retrieved from http://www.wwf.or.id/tentang_wwf/upa ya_kami/iklim_dan_energi/solusikami/ adaptasi/forest_fire.cfm 